\title{
The epidermal growth factor receptor mediates allergic airway remodelling
} in the rat

\author{
M. Tamaoka*, , M. Hassan*, , T. McGovern*, D. Ramos-Barbón*, T. Jo*, \\ Y. Yoshizawa\#, B. Tolloczko*, Q. Hamid* and J.G. Martin*
}

ABSTRACT: The chronicity of bronchial asthma is attributed to persistent airway inflammation and to a variety of structural changes, or remodelling, that includes smooth muscle and goblet cell hyperplasia.

To investigate the mechanisms of airway remodelling, the current authors used an established allergen (ovalbumin; OVA)-driven rodent model (the Brown Norway rat).

Brown Norway rats were sensitised to OVA and challenged three times at 5-day intervals to evoke airway remodelling. The effects of an epidermal growth factor (EGF) receptor inhibitor, AG1478, and a cysteinyl leukotriene-1 receptor antagonist, montelukast, on epithelial and airway smooth muscle (ASM) cell proliferation in vivo in response to repeated OVA challenge were tested. Three challenges with leukotriene $(L T) D_{4}$ were given, to examine their effects on remodelling with and without AG1478 pretreatment.

OVA challenges caused ASM hyperplasia, with an increase in mass, epithelial cell proliferation and goblet cell proliferation. AG1478 prevented the changes, as did montelukast. Multiple OVA challenges increased heparin-binding EGF-like growth factor but not EGF expression by airway epithelium. LTD $_{4}$ reproduced the changes in remodelling induced by OVA and this was blocked by AG1478.

Allergen-induced airway epithelial and airway smooth muscle remodelling is mediated by cysteinyl leukotrienes via the cysteinyl leukotriene-1 receptor with downstream effects on the epidermal growth factor receptor axis.

KEYWORDS: Allergy, inflammation, lung, signal transduction

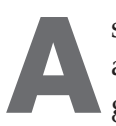
sthmatic airways often show extensive and complex remodelling [1-4]. The growth of smooth muscle has the potential to have the most significant pathophysiological consequences through excessive airway narrowing and airway hyperresponsiveness $[5,6]$. Increase in airway smooth muscle (ASM) in the airways has been associated with the severity of asthma [3,7], and when present in excess in the large airways is associated with mortality [8]. It is known that hyperplasia of smooth muscle in animal models [9-11] and both hyperplasia and hypertrophy in airway specimens from human subjects $[12,13]$ contribute to the increase in ASM mass. It has also been proposed that migration of subepithelial myofibroblasts may add to the tissue mass [7].

The mechanism of the growth response of muscle is quite uncertain, although several descriptive studies of growth factor expression in human airway tissues have been reported [14-16] and many growth factors have been demonstrated to have mitogenic effects on ASM in culture [17-20]. Cysteinyl (cys)-leukotrienes (LTs) are known to be involved in allergen-induced ASM cell proliferation in vivo $[21,22]$ but in vitro these substances are weak mitogens for ASM [23, 24]. In the sensitised mouse, cys- $\mathrm{LT}_{1}$ receptor $\left(\mathrm{cys}-\mathrm{LT}_{1} \mathrm{R}\right)$ antagonism prevents an increase in ASM thickening after repeated allergen challenge $[25,26]$. It is possible that the effects of cys-LTs in vivo are indirect and mediated by altering the expression of or potentiating the effects of tyrosine kinaselinked growth factors, such as epidermal growth factor (EGF) [27], or by upstream effects on immune responses to allergen challenge [28].

EGF has been shown to be upregulated in asthmatic human airways [16] and to stimulate ASM growth in vitro [23]. Heparin-binding EGFlike growth factor (HB-EGF), another ligand for
AFFILIATIONS

*Meakins-Christie Laboratories, Dept of Medicine, McGill University, Montreal, QC, Canada,

\#Dept of Integrative Pulmonology, Tokyo Medical and Dental University, Tokyo, Japan.

"Both authors contributed equally to the present article.

CORRESPONDENCE

J.G. Martin

Meakins-Christie Laboratories

Dept of Medicine

McGill University

3626 St Urbain Street

Montreal, QC, H2X 2P2

Canada

Fax: 15143987483

E-mail: james.martin@mcgill.ca

Received:

December 112007

Accepted after revision:

July 142008

SUPPORT STATEMENT

M. Tamaoka was supported by a grant from the Centre for Asthma in the Workplace funded by the Canadian Institutes of Health Research. D. Ramos-Barbón was the recipient of a Canadian Lung Association/B//Pfizer fellowship, and is currently supported by the National Health System of Spain (Fondo de Investigaciones Sanitarias, Fund No. CP04/00313).

\section{STATEMENT OF INTEREST}

A statement of interest for J.G. Martin and $D$. Ramos-Barbón can be found at www.erj.ersjournals.com/misc/ statments.shtml 
the EGF receptor (EGFR) has also been reported to be present in the airway epithelium of asthmatic subjects [29], and is mitogenic for vascular smooth muscle [30,31]. Both of these factors are, therefore, plausible candidates for the ASM hyperplasia in asthma. The EGFR has been implicated in goblet cell differentiation in a murine model of allergic asthma [26]. Stimulation of the EGFR causes goblet cell differentiation and upregulation of mucin genes [32]. The current authors hypothesised that allergen challenge increases the mass of ASM and airway goblet cell numbers through EGFR activation in vivo. To test this hypothesis, a rat model of allergen-induced airway remodelling was used [9-11], requiring only three allergen exposures for an increase in ASM mass to occur [33]. The present authors wished to elucidate the possible role of the EGFR in the apparent mitogenic effects of cys-LTs on ASM [21, 22] and in airway epithelial remodelling [26], and report that inhibition of the EGFR or the cys- $\mathrm{LT}_{1} \mathrm{R}$ completely abrogated allergeninduced ASM growth and goblet cell differentiation in the epithelium. Exogenous $\mathrm{LTD}_{4}$ mimicked allergen challenges in causing ASM and goblet cell hyperplasia by mechanisms involving the EGFR, indicating that the cys- $\mathrm{LT}_{1} \mathrm{R}$ is upstream of the EGFR in the remodelling cascade.

\section{MATERIALS AND METHODS}

\section{Animal preparation and treatment}

Brown Norway (BN) rats were sensitised with injections of $1 \mathrm{mg}$ of ovalbumin (OVA) and $100 \mathrm{mg}$ of alum subcutaneously and $2 \times 10^{9}$ heat-killed Bordetella pertussis bacilli i.p. Anaesthetised rats were challenged with either aerosolised OVA or saline delivered endotracheally on days 14, 19 and 24. The effects of AG1478 (an EGFR tyrosine kinase inhibitor) or montelukast (a cys-LT $\mathrm{T}_{1} \mathrm{R}$ antagonist), or appropriate vehicles, given i.p. or by gavage, respectively, $1 \mathrm{~h}$ prior to each challenge were tested in independent samples. In a third sample, unsensitised rats were administered $\mathrm{LTD}_{4}(100 \mu \mathrm{g})$ intratracheally three times at 5-day intervals, with or without pretreatment with AG1478. These groups were compared with vehicle-treated controls. Animals were killed 2 days after the final challenge, for tissue collection.

The study protocol was approved by the Animal Care Committee of McGill University (Montreal, QC, Canada).

\section{Immunostaining for HB-EGF, EGF and EGFR}

The left lung was formalin-fixed at $25 \mathrm{cmH}_{2} \mathrm{O}$ pressure and subsequently paraffin-embedded. Mid-sagittal and para-hilar sections $5 \mu \mathrm{m}$ thick were cut. To localise and quantify HB-EGF and EGF protein expression in an airway, immunostaining with rabbit polyclonal antibodies to human HB-EGF (R\&D Systems, Inc., Minneapolis, MN, USA) and to rat EGF (Biomedical Technologies, Inc., Stoughton, MA, USA) was performed. EGFR was immunostained using a rabbit polyclonal immunoglobulin (Ig)G antibody (Santa Cruz Biotechnology, Inc., Santa Cruz, CA, USA). Negative controls were run using the same concentration of isotype control IgG (R\&D Systems, Inc.) in place of each primary antibody. The signals were developed with Vector ${ }_{\circledR}$ Red (Vector Laboratories, Burlingame, CA, USA) and followed by methyl green (Sigma-Aldrich Co., St Louis, MO, USA) counterstaining. In order to perform a morphometric analysis of the number of airway cells positive for HB-EGF and EGF, a dose-response curve of immunostained tissues to primary antibody was performed and the concentration of antibody was chosen that produced definite but weakly positive staining in control tissues, in order to allow the detection of an increase in immunostaining, if present. The number of immunoreactive cells in the epithelium was counted by an observer (M. Hassan) who was blinded as to group status, and the results were expressed per $\mathrm{mm}$ of the perimeter of the basement membrane (PBM).

\section{Measurement of mass of ASM}

The mass of ASM was estimated from the measurement of the area of smooth muscle-specific $\alpha$-actin ( $\alpha$-SMA) immunoreactivity as previously described [33]. Briefly, sections were stained with a mouse monoclonal antibody to $\alpha$-SMA (clone 1A4; Sigma-Aldrich Co.) and a biotinylated horse anti-mouse IgG, rat adsorbed (Vector Laboratories). The signal was detected with Vector ${ }^{\circledR}$ Red. The area of ASM was traced using a camera lucida side arm attachment to the microscope and digitised. The mass of ASM was standardised for airway size by dividing the area of ASM by the square of the PBM.

\section{Quantification of proliferating ASM cells in vivo}

Proliferation of ASM cells was investigated using double immunostaining for proliferating cell nuclear antigen (PCNA) and $\alpha$-SMA using a monoclonal antibody to PCNA (Calbiochem, San Diego, CA, USA) as previously described [33]. Staining was preceded by high-temperature epitope unmasking in antigen retrieval solution (Vector Laboratories) and permeabilisation in $0.2 \%$ Triton X-100 (Sigma-Aldrich Co.). Sections were then blocked with 20\% horse serum (Vector Laboratories) in universal blocking solution (Dako Cytomation, Glostrup, Denmark), and a monoclonal antibody to PCNA was detected with biotinylated horse anti-mouse IgG, avidin/biotin-alkaline phosphatase complex, and 5-bromo-4-chloro-3-indolyl phosphate/nitroblue tetrazolium chromogen substrate (Vector Laboratories). Double immunostaining with anti- $\alpha$-SMA monoclonal antibody was developed with Vector ${ }^{\circledR}$ Red and followed by methyl green (Sigma-Aldrich Co.) counterstain. The number of PCNA-positive ASM cells was counted and corrected for airway size by dividing by the square of the PBM.

\section{Quantification of epithelial remodelling}

The turnover of epithelial cells was determined using PCNA staining. The goblet cells were enumerated on periodic acidSchiff (PAS)-stained tissues and expressed as the number of PAS-positive cells per mm PBM.

\section{Real-time quantitative PCR for growth factors in the lung and airway epithelial cells}

To investigate the mRNA expression of HB-EGF and EGF in the whole lung and airway epithelium after treatment, real-time quantitative PCR was performed. The right lung was snap frozen in liquid nitrogen and kept at $-80^{\circ} \mathrm{C}$. Total RNA was extracted from the frozen lungs using Trizol Reagent (Invitrogen, Carlsbad, CA, USA) according to the manufacturer's instructions. Tracheas were dissected out and immersed in RNAlater (QIAGEN, Hilden, Germany) overnight and epithelial cells were obtained by scraping the lumen of the trachea with a cell scraper. Total RNA was extracted from the epithelial cells using an RNeasy Mini Kit (QIAGEN) according to the manufacturer's instructions. Reverse transcription was performed using 

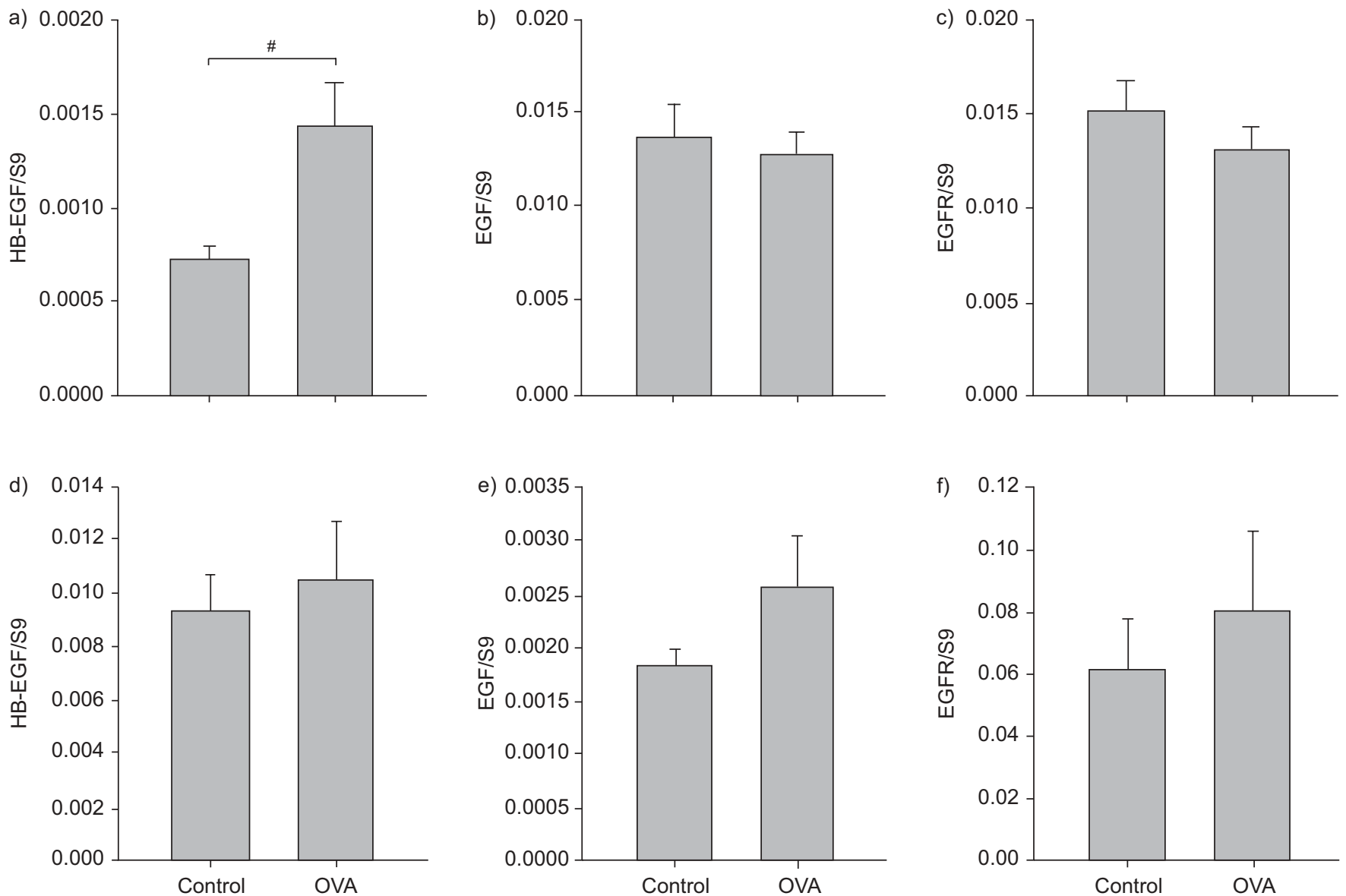

FIGURE 1. Heparin-binding epidermal growth factor (EGF)-like growth factor (HB-EGF; a and d), EGF (b and e) and EGF receptor (EGFR; c and f) mRNA expression in airway epithelial cells $(\mathrm{a}-\mathrm{c})$ and whole lung tissue $(\mathrm{d}-\mathrm{f})$ after repeated ovalbumin (OVA) challenge. The expression of HB-EGF, EGF, and EGFR mRNA was measured by realtime quantitative PCR and standardised for the housekeeping gene S9 in airway epithelial cells obtained from trachea by scraping the luminal surface after three consecutive OVA challenges at 5-day intervals. OVA challenges were delivered as an aerosol of 5\% OVA solution to endotracheally intubated anaesthetised rats. Data are presented as mean \pm SEM; $n=8$. ${ }^{*}: p=0.035$.

SuperScript II reverse transcriptase (Invitrogen). Real-time quantitative PCR was performed with the LightCycler (Roche, Basel, Switzerland) using FastStart DNA Master SYBR Green I (Roche). The sequences of HB-EGF primers were as previously described [34]. The primers for rat EGF, EGFR and ribosomal protein S9 were designed using web-based software, PrimerQuest (Integrated DNA Technologies, Leuven, Belgium). The sequences of each pair of primers were as follows. HB-EGF: 5'ACTTGGAAGGGACCGATCTGGA-3', 5'-TAGGGTCAGCCC ATGACACCTC-3'; EGF: 5'-TGCCTTGCCCTGACTCTAC-3', 5'-AGCCAATGACACAGTTGCAC-3'; EGFR: 5'-TCCCTTTGG AGAACCTGCAGATCA-3', 5'-GTTGCTAAATCGCACAGCA CCGAT-3'; S9: 5'-AGGATTTCTTGGAGAGAAGGCTGC-3' , 5' CTTCTGAGAGTCCAGGCGAACAAT-3'. Standard curves were established for each growth factor and a housekeeping gene. Briefly, PCR products were extracted from agarose gel and purified with the GFX PCR DNA and Gel Band Purification Kit (Amersham Biosciences (GE Healthcare Life Sciences), Piscataway, NJ, USA). The amount of PCR product was calculated using densitometry. By step dilution, $10^{1}-10^{10}$ copies of standard were made.

\section{Effects of $L T D_{4}, E G F$ and HB-EGF on proliferation of primary culture of rat ASM cells}

To assess the possibility that ASM growth following repeated OVA challenge involved interaction of the EGFR and $\mathrm{LTD}_{4}$ at the level of the smooth muscle itself, the effects of EGF and HB-EGF alone and in conjunction with $\mathrm{LTD}_{4}$ were tested on cultured ASM. Rat tracheas were dissected and excess connective tissue was removed [35]. Tissues were digested in elastase at $37^{\circ} \mathrm{C}$ for $30 \mathrm{~min}$ and subsequently placed on ice to stop the reaction. The tissues were allowed to stand and supernatant was collected. The tissue fragments remaining in the tube were washed with Hanks' balanced salt solution (HBSS) and the supernatant was collected. This procedure was repeated three times. Finally, cells were collected by centrifugation at 1,400 rpm for $5 \mathrm{~min}$ and resuspended in $25-\mathrm{cm}^{2}$ flasks in 1:1 Dulbecco's modified Eagle medium (DMEM):Ham's F12 medium supplemented with 10\% foetal bovine serum (FBS), $0.224 \% \mathrm{NaHCO}_{3}$ and $1 \%$ penicillin/ streptomycin in the presence of $5 \% \mathrm{CO}_{2}$. Cell culture reagents were purchased from GIBCO (Invitrogen). The phenotype was confirmed as previously described [35]. 

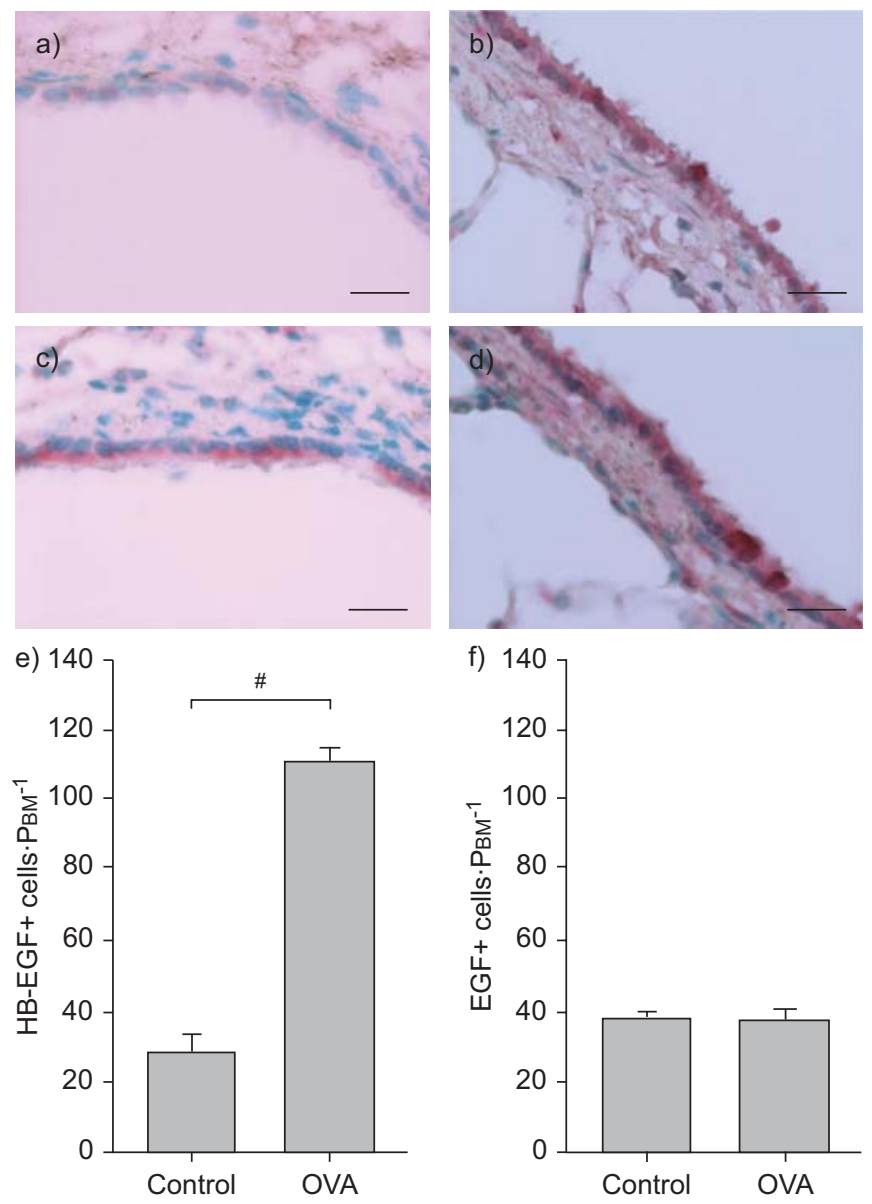

FIGURE 2. Multiple ovalbumin (OVA) challenge increased heparin-binding epidermal growth factor (EGF)-like growth factor (HB-EGF) protein expression in airway epithelial cells. Localisation and quantification of HB-EGF (a and c) and EGF ( $b$ and $d$ ) at protein level were performed by immunostaining and analysed morphometrically in saline controls ( $a$ and $b$ ) and in OVA-challenged rats ( $c$ and d). Immunoreactivity of HB-EGF was detected principally in airway epithelium and increased in an OVA-challenged animal ( $a$ and $c$ ). EGF was expressed strongly in airway epithelial cells and less strongly in airway smooth muscle cells and in some alveolar cells (b and d). HB-EGF-positive (e) and EGF-positive ( $f$ ) airway epithelial cells were counted and corrected using the perimeter of the basement membrane (PBM). HB-EGF-positive epithelial cells increased 3.5-fold in the OVA-challenged group. There was no change in EGF protein expression after OVA challenge. Data are presented as mean \pm SEM; $n=6$. Scale bars $=50 \mu \mathrm{m}$. ${ }^{\#}: \mathrm{p}<0.0001$.

Cells at passages 2-4 were used for the experiment. Cells were plated on 6-well plates (40,000 cells in $2 \mathrm{~mL}$ medium per well) and starved in DMEM with $0.2 \%$ bovine serum albumin (BSA) when they reached $\sim 70 \%$ confluency. After $48 \mathrm{~h}$ in DMEM with $0.2 \%$ BSA, cells were stimulated with either human HBEGF (1-10 ng $\cdot \mathrm{mL}^{-1}$; R\&D Systems, Inc.), $\mathrm{LTD}_{4}(1 \mu \mathrm{M}$; Biomol International, Plymouth Meeting, PA, USA) or a combination of HB-EGF and $\mathrm{LTD}_{4}$. In a separate series of experiments, cells were pretreated with montelukast (500 nM; Merck-Frosst Canada, Montreal, Canada) for 30 min before administration of $\mathrm{LTD}_{4}$. Cells were trypsinised with HBSS containing $0.25 \%$ trypsin and $0.02 \%$ EDTA to detach them from the plate. Trypsin was neutralised by adding DMEM:Ham's F12 with 10\% FBS, and cells were collected by centrifuging at 1,400 rpm for $5 \mathrm{~min}$ and resuspended in $1 \mathrm{~mL}$ of PBS. The cells were counted using a haemacytometer. For the bromodeoxyuridine (BrdU) incorporation assay, cells were starved and stimulated as described above and BrdU was added to each well $6 \mathrm{~h}$ after stimulation. Cells were harvested $18 \mathrm{~h}$ after BrdU ( $24 \mathrm{~h}$ after stimulation) and were processed for the flow cytometric detection of incorporated BrdU using a fluorescein isothiocyanate-BrdU Flow Kit (BD Biosciences, Mississauga, ON, Canada) according to the manufacturer's instructions.

\section{Effects of $L T D_{4}$ on intracellular calcium responses of cultured ASM cells}

To demonstrate the presence of functional cys-LT receptors on ASM, the changes in intracellular calcium in response to exposure to $\mathrm{LTD}_{4}(1 \mu \mathrm{M})$ were measured. Cytosolic calcium measurements were performed as previously described [36] ASM cells were incubated for $30 \mathrm{~min}$ at $37^{\circ} \mathrm{C}$ with Hanks' buffer $\left(\mathrm{NaCl} 137 \mathrm{mM}, \mathrm{NaHCO}_{3} 4.2 \mathrm{mM}\right.$, glucose $10 \mathrm{mM}$, $\mathrm{Na}_{2} \mathrm{HPO}_{4} 3 \mathrm{mM}, \quad \mathrm{KCl} 5.4 \mathrm{mM}, \mathrm{KH}_{2} \mathrm{PO}_{4} 0.4 \mathrm{mM}, \mathrm{CaCl}_{2}$ $1.3 \mathrm{mM}, \mathrm{MgCl}_{2} 0.5 \mathrm{mM}, \mathrm{MgSO}_{4} 0.8 \mathrm{mM}$, hydroxyethyl piperazine ethane sulphonic acid $5 \mathrm{mM}$ ) in the presence of $5 \mu \mathrm{M}$ Fura-2-acetoxymethylester. The loaded cells were washed and the cover slips were placed in a Leiden chamber (Medical Systems Corp, Greenville, NY, USA) containing $450 \mu$ L Hanks' buffer on the stage of an inverted microscope equipped for cell imaging with $40 \times$ oil immersion objective (Nikon, Tokyo, Japan). The images of the cells before and after stimulation with $\mathrm{LTD}_{4}$ were obtained using an intensified camera (Videoscope IC 200; Photon Technology International Inc., London, ON, Canada) and PTI software (Photon Technology International Inc.) at a single emission wavelength $(510 \mathrm{~nm})$ with double excitatory wavelengths (345 and $380 \mathrm{~nm}$ ). The fluorescence ratio $(345 / 380)$ was measured in individual cells and the free calcium was calculated using the Grynkiewicz formula [37].

\section{Statistical analysis}

Data are presented as mean \pm SEM. One-way ANOVA followed by unpaired two-tailed t-test was performed for the analysis. When data were not normally distributed, log transformation was applied. The Bonferroni correction was used to correct for multiple comparisons. Values of $\mathrm{p}<0.05$ were considered significant.

\section{RESULTS}

\section{Effects of allergen challenge on EGF and HB-EGF mRNA expression in whole lung and airway epithelium}

The effects of OVA sensitisation and challenge on the expression of mRNA for the two EGFR ligands, EGF and HB-EGF, as well as the EGFR, were examined, and their expression was standardised using the housekeeping gene S9. It was confirmed that $\mathrm{S} 9$ did not vary significantly among study groups and, furthermore, was highly correlated with the expression levels of two other housekeeping genes, $\beta$-actin and cyclophilin (data not shown). The expression of these growth factors was quantified in whole lung tissue using mRNA from lung homogenates and in the epithelium using cells harvested from the lower trachea by scraping. HB-EGF mRNA expression in tracheal epithelial cells was upregulated two-fold after multiple OVA challenges $(0.0014 \pm 0.00029$ in challenged cells versus $0.00073 \pm 0.000073$ in controls; $\mathrm{p}=0.035$; fig. 1a), while 

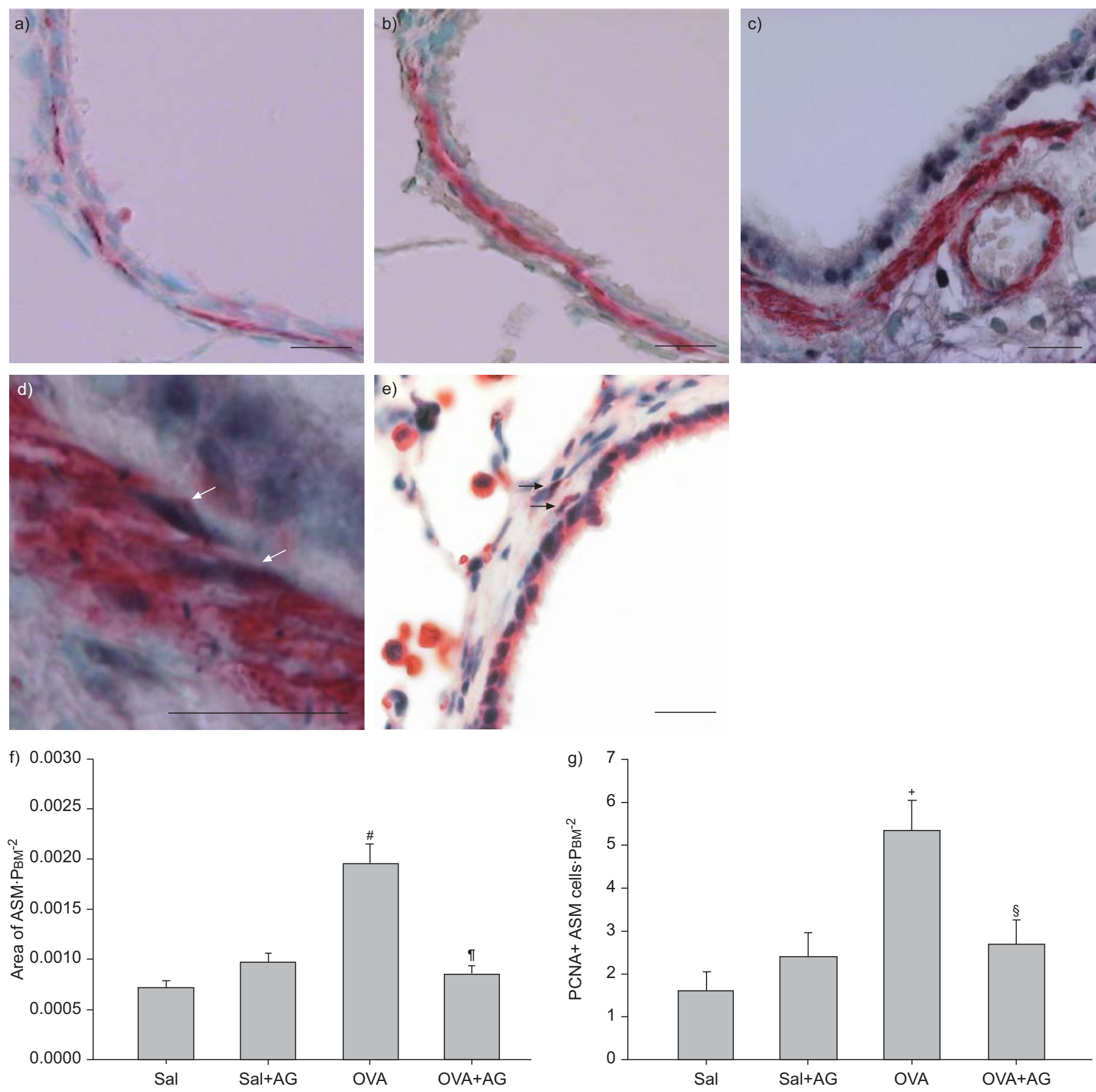

FIGURE 3. Epidermal growth factor receptor (EGFR) tyrosine kinase inhibitor AG1478 (AG) blocked airway smooth muscle (ASM) proliferation caused by multiple ovalbumin (OVA) challenge. Representative photomicrographs of smooth muscle-specific $\alpha$-actin ( $\alpha$-SMA) immunostaining of an airway from saline control (a) and multiple OVA-challenged group (b), showing ASM bundles in red. $c$ and d) Double immunostaining for proliferating cell nuclear antigen (PCNA) and $\alpha$-SMA. Dark-violet nuclear staining represents PCNA-positive ASM cells (arrows) and epithelial cells. e) Illustrative photomicrograph of EGFR immunoreactivity in epithelial cells, in subepithelial cells with spindle-shaped nuclei that are probably ASM cells (arrows) and in alveolar macrophages. f) Morphometric measurement of ASM mass. The area of ASM was standardised to the square of the perimeter of the basement membrane (РВM), and was greater in the OVA-challenged group ( $n=9)$ compared with the saline control (Sal; $n=6$ ) and reduced by the AG treatment $(n=6)$. g) PCNA-positive ASM cells increased 3.4-fold in the OVA group ( $n=9$ ) and AG significantly blocked this increase. AG $\left(5 \mathrm{mg} \cdot \mathrm{kg}^{-1}\right.$ in dimethyl sulphoxide) or vehicle was administered by i.p. injection $1 \mathrm{~h}$ prior to each challenge. Data are presented as mean $\pm \mathrm{SEM}$. Scale bars $=50 \mu \mathrm{m}$. \#: $p=0.004$ versus Sal control; ${ }^{\circ}: p=0.016$ versus OVA group; ${ }^{+}: p=0.001$ versus Sal control; ${ }^{s}: p=0.01$ versus OVA group.

EGF mRNA and EGFR did not show changes (EGF: $0.013 \pm 0.0011$ versus $0.014 \pm 0.0016$ for challenged cells versus controls, respectively, $\mathrm{p}=0.51$; EGFR: $0.013 \pm 0.0012$ versus
$0.015 \pm 0.0016, p=0.43$; fig. $1 b$ and $c)$. There was no detectable alteration in the expression of any of the three genes in whole lung tissues (fig. 1d-f). 

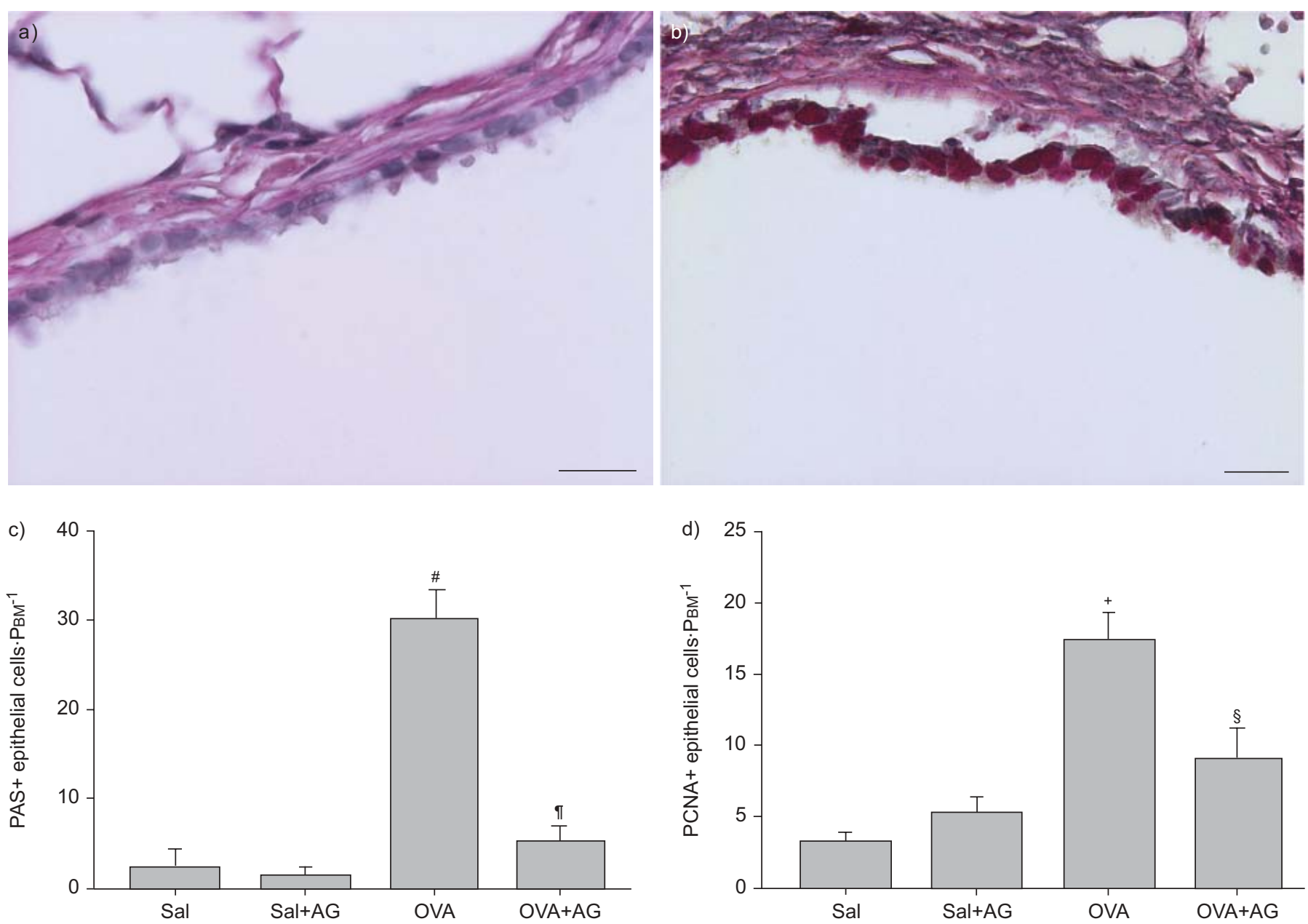

FIGURE 4. Epidermal growth factor receptor tyrosine kinase inhibitor AG1478 (AG) blocked airway epithelial remodelling caused by multiple ovalbumin (OVA) challenge. Representative photomicrographs of periodic acid-Schiff (PAS) staining from a saline (Sal) control animal (a) and a multiply OVA-challenged animal (b), showing increased goblet cells in an OVA-challenged animal. c) PAS-positive epithelial cells were counted and corrected using the perimeter of the basement membrane (PBM). They increased 8-fold after multiple OVA challenge. AG reduced PAS-positive cells induced by multiple OVA challenge. d) Multiple OVA challenge caused proliferation of airway epithelial cells detected by proliferating cell nuclear antigen (PCNA). This was blocked by AG. Data are presented as mean \pm sEM; $n=6$. Scale bars $=50 \mu \mathrm{m}$. ${ }^{*}: \mathrm{p}=0.0042$ versus Sal control; ${ }^{\bullet}: p=0.0056$ versus OVA group; ${ }^{+}: p=0.0013$ versus Sal control; ${ }^{s}: p=0.017$ versus OVA group.

\section{Immunolocalisation and morphometric assessment of HB- EGF and EGF expression after OVA challenges}

Immunostaining was performed to localise the site of the expression of HB-EGF and EGF in the airways. Figure 2 shows photomicrographs and data for immunoreactive HB-EGF and EGF. HB-EGF was expressed mainly in airway epithelium and the morphometric assessment of HB-EGF immunoreactivity demonstrated a significant increase in OVA-challenged animals (110.7 \pm 4.15 cells $\cdot \mathrm{mm}^{-1}$ PBM) compared with controls $\left(28.2 \pm 4.91\right.$ cells $\cdot \mathrm{mm}^{-1}$ Рвм; $\mathrm{p}<0.0001$; fig. $2 \mathrm{a}, \mathrm{c}$ and e). EGF was expressed strongly in airway epithelial cells and less strongly in ASM cells and in some alveolar cells. There was evidence of constitutive expression of EGF but there was no difference in the number of immunoreactive epithelial cells between the treatment groups $\left(36.32 \pm 3.23\right.$ cells $\cdot \mathrm{mm}^{-1}$ in OVAchallenged animals versus $35.88 \pm 2.86$ in controls; $p=0.92$; fig. $2 b, d$ and f). These observations are consistent with the results of quantitative real-time PCR for mRNA obtained from tracheal epithelial cells (fig. 1a-c).

\section{Effect of EGFR blockade on allergen-induced ASM remodelling: mass of ASM}

The effect of EGFR inhibition on OVA-induced increase in ASM was investigated. Contractile tissue was identified by immunohistochemistry for $\alpha$-SMA and is illustrated in figure 3 ( $a$ and $b$ ). The mass of ASM was determined morphometrically and expressed as an area of tissue corrected for airway size (ASM.PBM ${ }^{-2}$; fig. 3f). The size-corrected area of ASM showed a 2.8-fold increase after OVA inhalation challenges $(0.0020 \pm$ $0.0004)$ compared with saline-challenged controls $(0.0007 \pm$ $0.0002 ; \mathrm{p}=0.0007)$. This increase in ASM mass was significantly suppressed by treatment with AG1478, an EGFR-specific tyrosine kinase inhibitor $(0.0009 \pm 0.0002 ; \mathrm{p}=0.0011)$.

\section{Effect of EGFR blockade on allergen-induced proliferation of ASM cells}

In order to confirm that ASM cells were undergoing hyperplastic growth, PCNA-positive nuclei were immunolocalised to $\alpha$-SMA-positive cells; an illustrative example is 

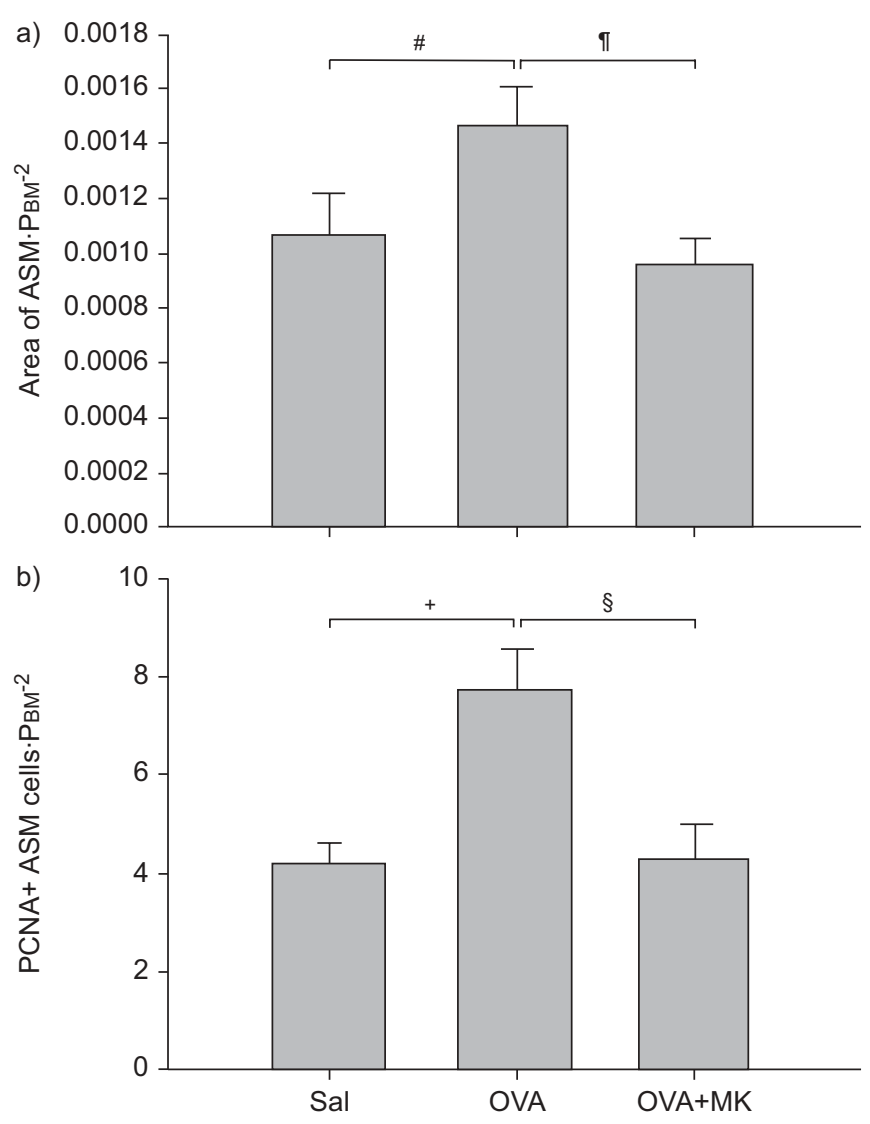

FIGURE 5. The increase of airway smooth muscle (ASM) mass after multiple ovalbumin (OVA) challenges was suppressed by the cysteinyl-leukotriene-1 receptor antagonist montelukast (MK). The mass of ASM and the number of proliferating cell nuclear antigen (PCNA)-positive ASM cells were standardised to the square of the perimeter of the basement membrane (РBM). a) The OVAchallenged group $(n=7)$ showed a significant increase in ASM mass compared with saline control (Sal; $n=9)$. ASM was reduced in the OVA-challenged and MK-treated group $(n=9)$ compared with the OVA-challenged group. b) PCNA-positive ASM cells increased 1.9-fold after OVA challenges. This increase was prevented by MK MK was administered in a dose of $3 \mathrm{mg} \cdot \mathrm{kg}^{-1}$ in methylcellulose by gavage $1 \mathrm{~h}$ prior to challenges. Data are presented as mean \pm SEM. ${ }^{\#}: p=0.041 ;{ }^{\natural}: p=0.036$ $+: p=0.0059 ;{ }^{\text {s: }} p=0.016$.

shown in figure $3 \mathrm{c}$ and $\mathrm{d}$. The number of proliferating ASM cells detected by PCNA staining was 3.4-fold higher in OVAchallenged animals $\left(5.4 \pm 0.69\right.$ cells $\left.\cdot \mathrm{mm}^{-2}\right)$ compared with saline controls (1.6 $\pm 0.46 ; p=0.001$; fig. $3 g$ ), confirming proliferation of ASM in response to allergen challenge. The EGFR was expressed on epithelial cells and ASM, as well as on alveolar macrophages. Epithelial expression of the EGFR and expression in subepithelial cells located in the smooth muscle layer are illustrated in figure 3e. AG1478 blocked the increase of proliferating ASM cells after multiple OVA challenges $(p=0.01)$.

\section{Effect of EGFR blockade on allergen-induced airway epithelial remodelling}

Allergic airway remodelling involves phenotypic changes of airway epithelial cells, most notably an increase in goblet cells. The increase in goblet cells evoked by allergen challenges is illustrated in figure 4 ( $\mathrm{a}$ and $\mathrm{b}$ ). Quantification of the PASpositive cells showed an 8-fold increase after OVA challenges $(\mathrm{p}=0.004$; fig. $4 \mathrm{c})$. This increase was significantly reduced by AG1478 $(p=0.006)$. The number of proliferating airway epithelial cells, identified by PCNA staining, also increased after multiple allergen challenges $\left(17.4 \pm 1.87 \mathrm{cells} \cdot \mathrm{mm}^{-1}\right.$, $\mathrm{p}=0.001$; fig. $4 \mathrm{~d})$. This increase was also blocked by AG1478 $(9.1 \pm 2.1 ; \mathrm{p}=0.017)$.

\section{Effects of the cys-LT $R$ antagonist montelukast on ASM mass and hyperplasia after multiple OVA challenges}

In order to confirm the role of the cys- $\mathrm{LT}_{1} \mathrm{R}$ in airway remodelling, repeated allergen challenge was performed in a separate series of animals, some of which were pretreated with montelukast, a specific cys- $\mathrm{LT}_{1} \mathrm{R}$ antagonist. Morphometric analysis of OVA-induced changes in ASM mass was performed, with and without montelukast pretreatment. As before, the ASM mass increased in OVA-challenged rats $(0.0015 \pm 0.00014$ $\mathrm{p}=0.04)$ compared with saline-challenged control animals $(0.0011 \pm 0.00016)$, and the OVA-induced increase in ASM mass was prevented by montelukast pretreatment $(0.0010 \pm 0.0001$; $\mathrm{p}=0.01$ ), indicating that it was dependent on cys-LT $\mathrm{T}_{1} \mathrm{R}$. The number of PCNA-positive ASM cells in OVA-challenged rats, determined morphometrically, was also increased after OVA challenge and significantly reduced by montelukast (fig. 5).

\section{Effects of repeated $L T D_{4}$ challenge on ASM growth and goblet cell proliferation}

To examine the potential for $\mathrm{LTD}_{4}$ alone to induce airway remodelling in naïve rats, animals were exposed to $\mathrm{LTD}_{4}$ on three occasions at 5-day intervals, mimicking the repeated OVA challenges. There was significant remodelling of both the ASM and the goblet cells in these animals; ASM increased more than two-fold and goblet cell numbers increased approximately four-fold (fig. 6).

\section{Effects of inhibition of the EGFR on $L T D_{4}$-induced airway remodelling}

To evaluate the possibility that $\mathrm{LTD}_{4}$ was acting through the EGFR, rats undergoing repeated $\mathrm{LTD}_{4}$ challenges were pretreated with AG1478, in the same doses that were effective in preventing allergen-induced ASM and epithelial remodelling. The inhibition of the EGFR with AG1478 significantly reduced both goblet cell and ASM hyperplasia, as assessed by PCNA immunoreactivity (fig. 6). Goblet cell numbers and ASM area were proportionately reduced.

\section{Morphometric assessment of epithelial HB-EGF expression after $L T D_{4}$ challenges}

The effect of repeated challenges with $\mathrm{LTD}_{4}$ on epithelial expression of HB-EGF was assessed morphometrically. The expression increased significantly in $\mathrm{LTD}_{4}$-challenged animals compared with controls (fig. 7). The effect was inhibited entirely by montelukast, showing that it was mediated by the cys- $\mathrm{LT}_{1} \mathrm{R}$.

Effect of $L T D_{4}$ on ASM proliferation in vitro, alone and with concomitant EGFR stimulation

The ASM itself is a potential site of interaction of $\mathrm{LTD}_{4}$ and the EGFR axis, through synergy or transactivation of the EGFR. It was confirmed that functional cys-LT receptors were present on ASM cells by demonstrating a rise in intracellular calcium 

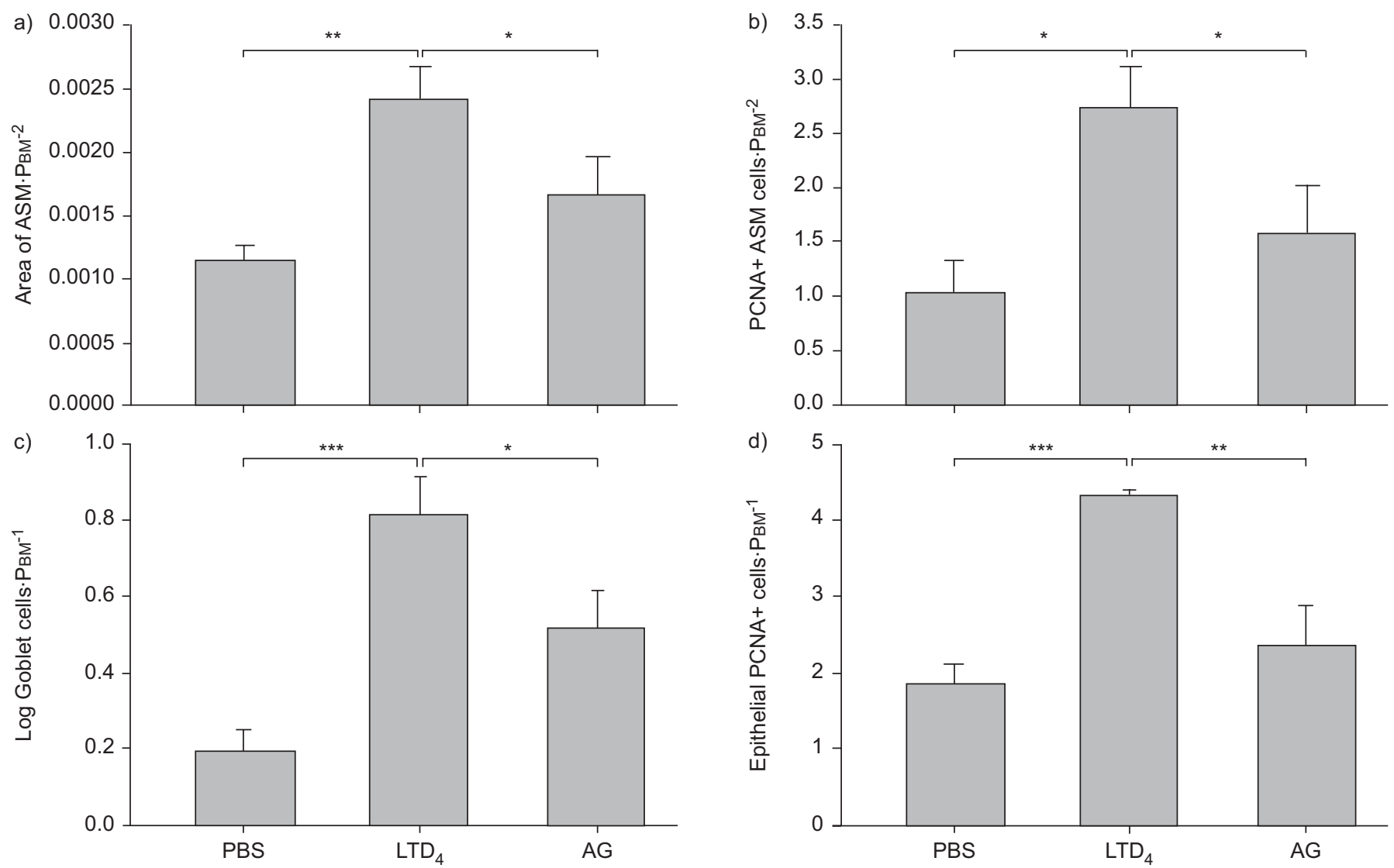

FIGURE 6. Repeated leukotriene ( $\left(\mathrm{LT} \mathrm{D}_{4}\right.$ instillations caused airway smooth muscle (ASM) growth and goblet cell proliferation. a) The ASM area was determined by morphometry and was increased by three intratracheal instillations of $1 \mu \mathrm{g}$ of $\mathrm{LTD}_{4}$ in $100 \mu \mathrm{L}$ PBS. The increase was blocked by AG1478 (AG). b) The proliferating cell nuclear antigen (PCNA)-immunoreactive cells were localised to ASM by double immunostaining for smooth muscle-specific $\alpha$-actin. The number of cells was increased following $\mathrm{LTD}_{4}$ and this increase was blocked by AG. c) LTD 4 increased goblet cell numbers as assessed by periodic acid-Schiff staining. The increase in goblet cells was blocked by AG. d) There was an increase in epithelial PCNA-immunoreactive cells after $\mathrm{LTD}_{4}$. AG blocked the increase in PCNA-positive epithelial cells. PBM: perimeter of the basement membrane. *: $p<0.05 ; * *: p<0.01 ; * * *: p<0.001$.

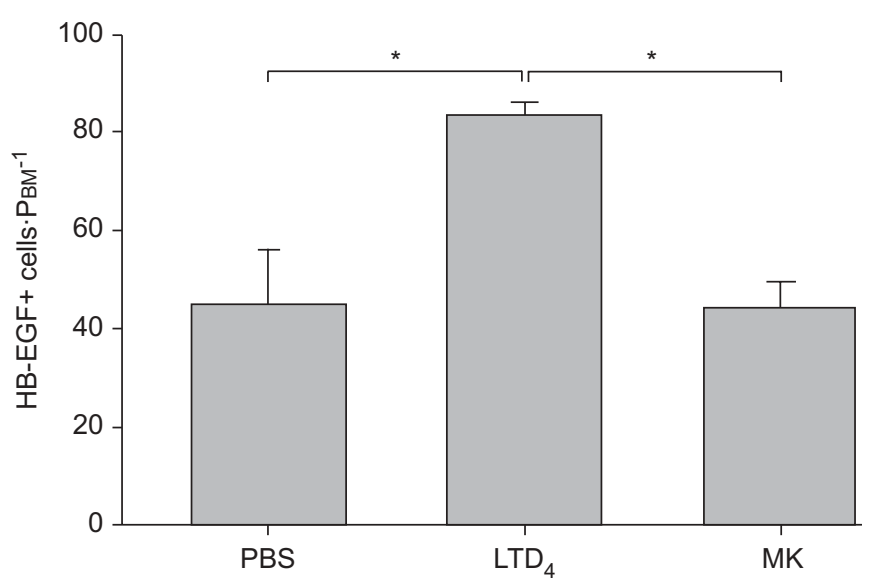

FIGURE 7. Effects of leukotriene $(\mathrm{LT}) \mathrm{D}_{4}$ challenges on epithelial heparinbinding epidermal growth factor-like growth factor (HB-EGF) immunoreactivity. $\mathrm{LTD}_{4}$ was administered by intratracheal instillation three times at 5-day intervals and $48 \mathrm{~h}$ after the third challenge the tissues were harvested for analysis. The number of HB-EGF-expressing cells increased almost two-fold compared with PBS control, and this increase was significantly inhibited by montelukast (MK). PBM: perimeter of the basement membrane. ${ }^{*}: p<0.05$. in response to exposure of cells to $\mathrm{LTD}_{4}(1 \mu \mathrm{M}$; fig. 8a). To test the possibility that cys-LTs act in synergy with the EGFR in promoting smooth muscle cell growth, the mitogenic effects of HB-EGF and EGF alone and in combination with $\mathrm{LTD}_{4}$ on ASM from BN rats in primary culture were examined, using BrdU incorporation and cell counting. HB-EGF $10 \mathrm{ng} \cdot \mathrm{mL}^{-1}$ stimulated ASM proliferation significantly, as measured both by BrdU incorporation (fig. 8b) and cell counting (fig. 8c). Exogenous $\mathrm{LTD}_{4}$ did not increase BrdU incorporation or cell number beyond the values observed after HB-EGF alone. Similar results were obtained for EGF and EGF plus $\mathrm{LTD}_{4}$ (data not shown). AG1478 inhibited the growth response to EGF and HB-EGF, whereas it did not reduce the response to platelet-derived growth factor or to the multi-mitogenic stimulus of FBS (10\%; data not shown).

\section{DISCUSSION}

Repeated allergen challenge of the actively sensitised $\mathrm{BN}$ rat caused hyperplasia of ASM that led to a substantial increase in ASM mass. It also caused the proliferation of airway epithelial cells and goblet cell differentiation. Increased expression of the growth factor HB-EGF in the airway epithelium, but not EGF, occurred after repeated OVA challenge. ASM hyperplasia and 

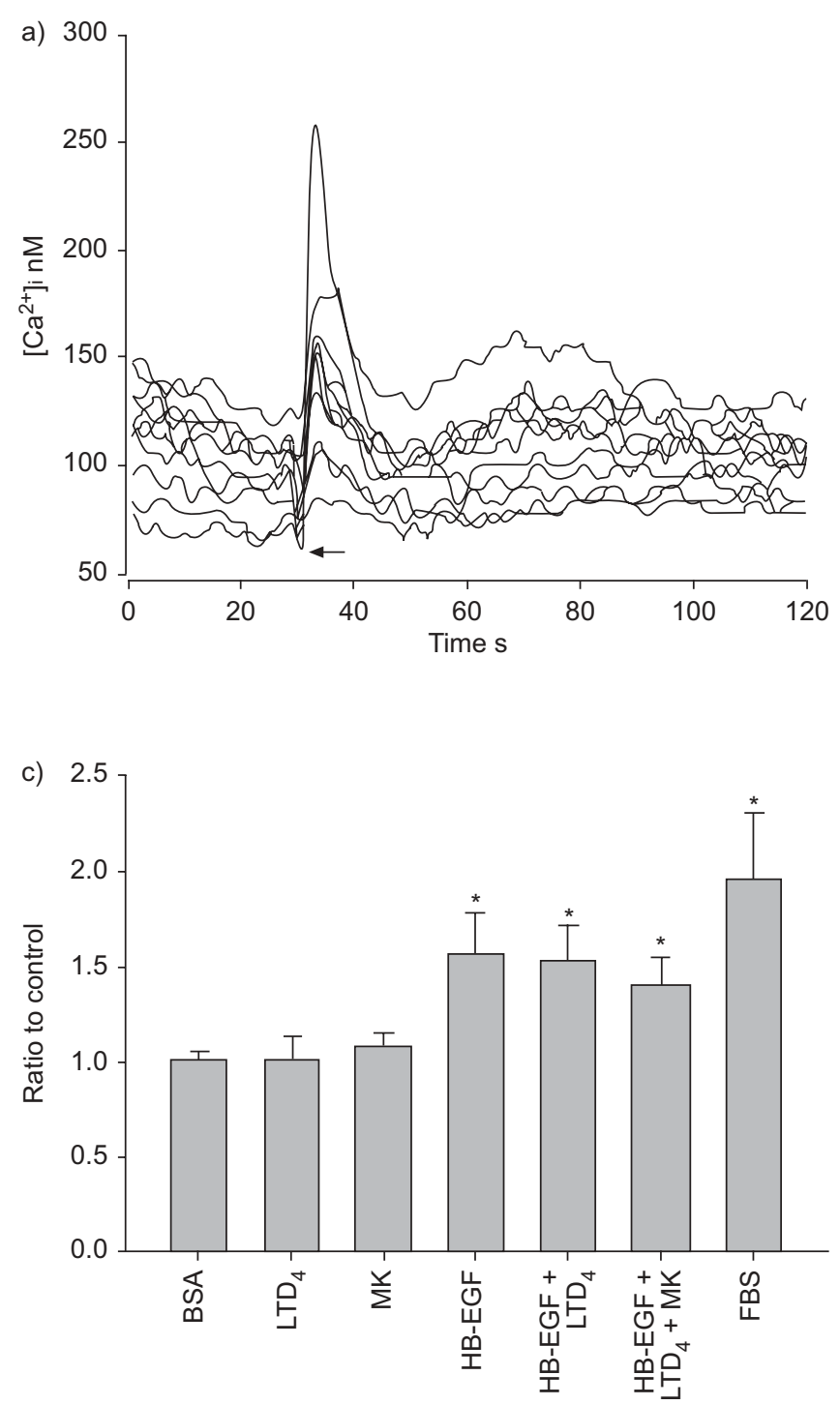

goblet cell differentiation were prevented by pretreatment with a selective EGFR tyrosine kinase inhibitor, indicating a primary role for the EGFR in these components of allergen-induced airway remodelling. Montelukast also blocked allergeninduced ASM hyperplasia, confirming the role of the cys$\mathrm{LT}_{1} \mathrm{R}$ in the process. Intratracheal instillation of $\mathrm{LTD}_{4}$ caused remodelling similar to OVA challenge when administered alone to naive rats, and these remodelling changes were inhibited by AG1478, indicating that $\mathrm{LTD}_{4}$ mediates remodelling by indirect means through the EGFR. $\mathrm{LTD}_{4}$ did not have detectable direct mitogenic effects on rat ASM in culture and did not interact with the EGFR in inducing ASM growth.

Although a number of growth factors have the potential to increase ASM growth, based on activity in vitro, the current authors chose to focus on the EGFR ligands, EGF and HB-EGF, because of the recent evidence that some of these ligands may be upregulated in human asthmatic tissues [29]. Increased immunoreactivity of EGF has been shown in the submucosa of asthmatic subjects [16] and in bronchial epithelium, glands and smooth muscle in asthmatic human airways [29]. The functional significance of EGFR and its ligands in the airways

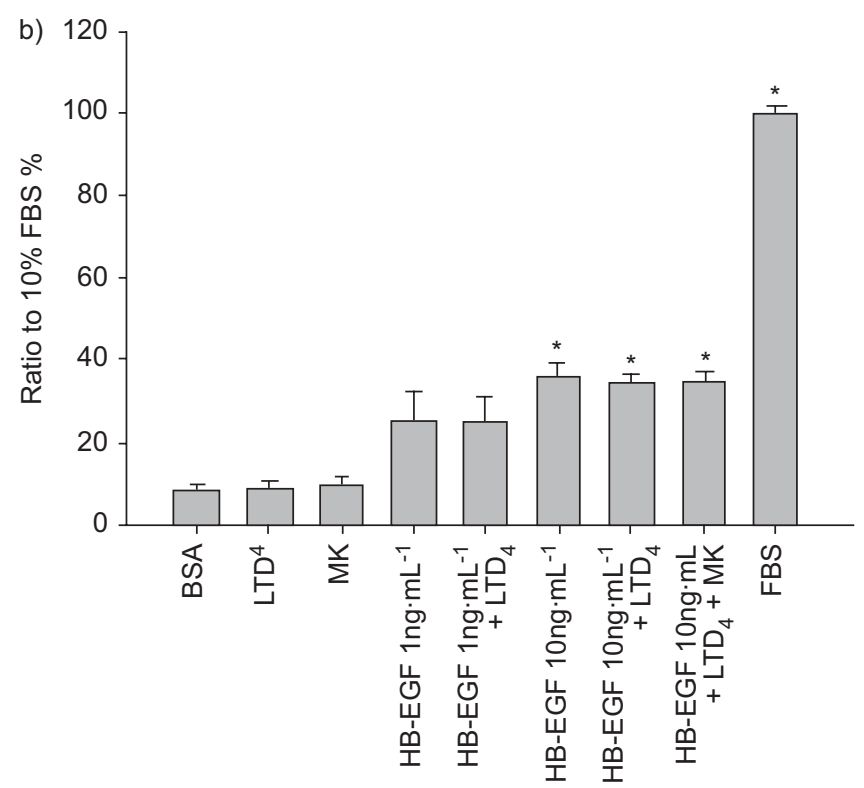

FIGURE 8. Heparin-binding epidermal growth factor-like growth factor (HBEGF) was mitogenic to Brown Norway rat airway smooth muscle (ASM) cells in vitro. a) A representative example of ASM cell calcium responses to $1 \mu \mathrm{M}$ leukotriene $\left(\mathrm{LT} \mathrm{D}_{4}\right.$. Each line represents the calcium transient in a single cell. Agonist application is indicated by an arrow. b) Bromodeoxyuridine (BrdU) incorporation measured by flow cytometry, with the number of BrdU-incorporating cells expressed as a percentage of that of the cells treated in $10 \%$ foetal bovine serum (FBS). Cells treated in HB-EGF $\left(10 \mathrm{ng} \cdot \mathrm{mL}^{-1}\right)$ alone and HB-EGF $\left(10 \mathrm{ng} \cdot \mathrm{mL}^{-1}\right)$ plus $\mathrm{LTD}_{4}(1 \mu \mathrm{M})$ showed a four-fold increase in BrdU incorporation compared with the $0.2 \%$ bovine serum albumin (BSA) control. $\mathrm{LTD}_{4}$ did not change BrdU incorporation or affect the mitogenic effect of HB-EGF. Montelukast (MK; $500 \mathrm{nM}$ ) did not affect BrdU incorporation. c) Cell counting, with the number of cells expressed as the ratio to that of the control $(0.2 \% \mathrm{BSA})$. In agreement with the $\mathrm{BrdU}$ incorporation study, HB-EGF $\left(10 \mathrm{ng} \cdot \mathrm{mL}^{-1}\right)$ alone increased cell numbers 1.5 -fold, whereas neither $\mathrm{LTD}_{4}$ $(1 \mu \mathrm{M})$ nor MK $(500 \mathrm{nM})$ affected cell numbers. Data are presented as mean \pm SEM; $n=3$. * $p<0.05$ versus BSA control.

of asthmatic subjects is not clear. The present data shed light on the role of the EGFR and suggest a possible candidate ligand for the receptor in allergen-induced remodelling of epithelium and ASM in vivo. The inhibition of ASM growth in vivo by the specific EGFR inhibitor AG1478 was virtually complete and goblet cell differentiation was also reduced to basal levels. EGFR has been demonstrated to be involved in goblet cell metaplasia following allergen challenge using a murine model but its role in ASM remodelling has not been examined in any detail in vivo [26]. The present study did not find EGF or EGFR upregulation at the mRNA level in either whole lung specimens or isolated epithelial cells, suggesting that regulation of proliferation does not result from alterations in the levels of EGFR or of EGF itself. The upregulation of HBEGF provides an alternative mechanism to account for the observed importance of the EGFR in remodelling although the data do not exclude a role for alternative EGFR ligands.

The relationship between the EGFR and cys-LTs in mediating airway remodelling is not clear. The completeness of the inhibition of remodelling of ASM and epithelium by the specific antagonists for the EGFR and cys- $\mathrm{LT}_{1} \mathrm{R}$ suggested a 
possible interaction of the pathways mediating their effects. Cys-LTs are the principal mediators of allergic airway narrowing [36-41]. The present data are consistent with their role in remodelling, as demonstrated in several previous studies [21, 22, 25, 26]. The current authors expected that inhibition of the EGFR might diminish the remodelling effects of $\mathrm{LTD}_{4}$ itself because of the reported role of mechanical stresses placed on the epithelium, such as would be caused by bronchoconstriction in releasing HB-EGF from airway epithelial cells [42]. Consistent with these reported findings, the inhibition of the EGFR by AG1478 prevented LTD $_{4}$-induced remodelling. Additionally, repeated exposures of the airways to $\mathrm{LTD}_{4}$ caused an upregulation of HB-EGF, suggesting the possibility that this ligand may be responsible for the observed remodelling mediated via the EGFR. Direct evidence of release of HB-EGF by $\mathrm{LTD}_{4}$ is required to confirm this hypothesis.

An interaction of $\mathrm{LTD}_{4}$ and the EGFR on the ASM itself was sought. $\mathrm{LTD}_{4}$ has been shown to cause EGFR transactivation in cultured human ASM cells [43]. In human fibroblasts, $\mathrm{LTD}_{4}$ also synergises with the EGFR but by a mechanism that does not involve receptor transactivation [27]. In contrast to data on human ASM [23, 43] and fibroblasts [27], there was no evidence of a mitogenic effect of $\mathrm{LTD}_{4}$ nor was an interaction demonstrable between $\mathrm{LTD}_{4}$ and either HB-EGF or EGF in the rat ASM, despite the demonstrable presence of functional cysLT receptors on the ASM in culture. The reason for the discrepancy between the rat and human ASM cells is not clear.

It is possible that, in addition to remodelling mediated by downstream effects on the EGFR axis, there may be effects of cys-LTs released following OVA challenge at upstream sites involving the inflammatory cascade. The cys-LT $\mathrm{T}_{1} \mathrm{R}$ has been implicated in the genesis of T-helper cell type 2 inflammation through effects on dendritic cell function [28]. Consistent with an immunomodulatory action of the cys-LTs, montelukast reduces airway eosinophilia and interleukin-5 in the allergenchallenged $\mathrm{BN}$ rat, indicating an anti-inflammatory action involving T-cells [44].

In conclusion, the present study indicates that both the epidermal growth factor receptor and the cysteinylleukotriene-1 receptor are necessary for some of the characteristics of airway remodelling following allergen challenge. However, the cysteinyl-leukotriene- 1 receptor is upstream of the epidermal growth factor receptor in the remodelling process. The ligand for the epidermal growth factor receptor is possibly heparin-binding epidermal growth factor-like growth factor because it is upregulated by allergen and leukotriene $\mathrm{D}_{4}$ challenges. Cysteinyl-leukotrienes released by allergen challenge may release, in turn, heparin-binding epidermal growth factor-like growth factor, which then mediates the epithelial and airway smooth muscle cell remodelling. However, whether this phenomenon indeed occurs is an issue that requires further study.

\section{REFERENCES}

1 Dunnill MS, Massarella GR, Anderson JA. A comparison of the quantitative anatomy of the bronchi in normal subjects, in status asthmaticus, in chronic bronchitis, and in emphysema. Thorax 1969; 24: 176-179.
2 Flood-Page P, Menzies-Gow A, Phipps S, et al. Anti-IL-5 treatment reduces deposition of ECM proteins in the bronchial subepithelial basement membrane of mild atopic asthmatics. J Clin Invest 2003; 112: 1029-1036.

3 Pepe C, Foley S, Shannon J, et al. Differences in airway remodeling between subjects with severe and moderate asthma. J Allergy Clin Immunol 2005; 116: 544-549.

4 Jeffery PK. Remodeling in asthma and chronic obstructive lung disease. Am J Respir Crit Care Med 2001; 164: Suppl, S28-S38.

5 Lambert RK, Wiggs BR, Kuwano K, Hogg JC, Pare PD. Functional significance of increased airway smooth muscle in asthma and COPD. J Appl Physiol 1993; 74: 2771-2781.

6 Macklem PT. A theoretical analysis of the effect of airway smooth muscle load on airway narrowing. Am J Respir Crit Care Med 1996; 153: 83-89.

7 Benayoun L, Druilhe A, Dombret MC, Aubier M, Pretolani M. Airway structural alterations selectively associated with severe asthma. Am J Respir Crit Care Med 2003; 167: 1360-1368.

8 Carroll N, Elliot J, Morton A, James A. The structure of large and small airways in nonfatal and fatal asthma. Am Rev Respir Dis 1993; 147: 405-410.

9 Sapienza S, Du T, Eidelman DH, Wang NS, Martin JG. Structural changes in the airways of sensitized brown Norway rats after antigen challenge. Am Rev Respir Dis 1991; 144: 423-427.

10 Salmon M, Walsh DA, Koto H, Barnes PJ, Chung KF. Repeated allergen exposure of sensitized Brown-Norway rats induces airway cell DNA synthesis and remodelling. Eur Respir J 1999; 14: 633-641.

11 Panettieri RA Jr, Murray RK, Eszterhas AJ, Bilgen G, Martin JG. Repeated allergen inhalations induce DNA synthesis in airway smooth muscle and epithelial cells in vivo. Am J Physiol Lung Cell Mol Physiol 1998; 274: L417-L424.

12 Heard BE, Hossain S. Hyperplasia of bronchial muscle in asthma. J Pathol 1973; 110: 319-331.

13 Ebina M, Takahashi T, Chiba T, Motomiya M. Cellular hypertrophy and hyperplasia of airway smooth muscles underlying bronchial asthma. A 3-D morphometric study. Am Rev Respir Dis 1993; 148: 720-726.

14 Chanez P, Vignola M, Stenger R, Vic P, Michel FB, Bousquet J. Platelet-derived growth factor in asthma. Allergy 1995; 50: 878-883.

15 Vignola AM, Chanez P, Chiappara G, et al. Transforming growth factor- $\beta$ expression in mucosal biopsies in asthma and chronic bronchitis. Am J Respir Crit Care Med 1997; 156: 591-599.

16 Amishima M, Munakata M, Nasuhara Y, et al. Expression of epidermal growth factor and epidermal growth factor receptor immunoreactivity in the asthmatic human airway. Am J Respir Crit Care Med 1998; 157: 1907-1912.

17 Noveral JP, Bhala A, Hintz RL, Grunstein MM, Cohen P. Insulin-like growth factor axis in airway smooth muscle cells. Am J Physiol 1994; 267: L761-L765.

18 Stewart AG, Grigoriadis G, Harris T. Mitogenic actions of endothelin-1 and epidermal growth factor in cultured airway smooth muscle. Clin Exp Pharmacol Physiol 1994; 21: 277-285.

19 Zacour ME, Tolloczko B, Martin JG. Calcium and growth responses of hyperresponsive airway smooth muscle to 
different isoforms of platelet-derived growth factor (PDGF). Can J Physiol Pharmacol 2000; 78: 867-873.

20 Hirst SJ, Barnes PJ, Twort CH. PDGF isoform-induced proliferation and receptor expression in human cultured airway smooth muscle cells. Am J Physiol 1996; 270: L415-L428.

21 Wang CG, Du T, Xu LJ, Martin JG. Role of leukotriene $\mathrm{D}_{4}$ in allergen-induced increases in airway smooth muscle in the rat. Am Rev Respir Dis 1993; 148: 413-417.

22 Salmon M, Walsh DA, Huang TJ, et al. Involvement of cysteinyl leukotrienes in airway smooth muscle cell DNA synthesis after repeated allergen exposure in sensitized Brown Norway rats. Br J Pharmacol 1999; 127: 1151-1158.

23 Panettieri RA, Tan EM, Ciocca V, Luttmann MA, Leonard TB, Hay DW. Effects of $\mathrm{LTD}_{4}$ on human airway smooth muscle cell proliferation, matrix expression, and contraction in vitro: differential sensitivity to cysteinyl leukotriene receptor antagonists. Am J Respir Cell Mol Biol 1998; 19: 453-461.

24 Espinosa K, Bosse Y, Stankova J, Rola-Pleszczynski M. CysLT1 receptor upregulation by TGF- $\beta$ and IL-13 is associated with bronchial smooth muscle cell proliferation in response to $\mathrm{LTD}_{4}$. J Allergy Clin Immunol 2003; 111: 1032-1040.

25 Henderson WR Jr, Tang LO, Chu SJ, et al. A role for cysteinyl leukotrienes in airway remodeling in a mouse asthma model. Am J Respir Crit Care Med 2002; 165: 108-116.

26 Vargaftig BB, Singer M. Leukotrienes mediate part of Ovainduced lung effects in mice via EGFR. Am J Physiol Lung Cell Mol Physiol 2003; 285: L808-L818.

27 Yoshisue H, Kirkham-Brown J, Healy E, Holgate ST, Sampson AP, Davies DE. Cysteinyl leukotrienes synergize with growth factors to induce proliferation of human bronchial fibroblasts. J Allergy Clin Immunol 2007; 119: 132-140.

28 Machida I, Matsuse H, Kondo Y, et al. Cysteinyl leukotrienes regulate dendritic cell functions in a murine model of asthma. J Immunol 2004; 172: 1833-1838.

29 Polosa R, Puddicombe SM, Krishna MT, et al. Expression of c-erbB receptors and ligands in the bronchial epithelium of asthmatic subjects. J Allergy Clin Immunol 2002; 109: 75-81.

30 Higashiyama S, Abraham JA, Miller J, Fiddes JC, Klagsbrun M. A heparin-binding growth factor secreted by macrophage-like cells that is related to EGF. Science 1991; 251: 936-939.

31 Nakano T, Raines EW, Abraham JA, et al. Glucocorticoid inhibits thrombin-induced expression of platelet-derived growth factor A-chain and heparin-binding epidermal growth factor-like growth factor in human aortic smooth muscle cells. J Biol Chem 1993; 268: 22941-22947.
32 Takeyama K, Dabbagh K, Lee HM, et al. Epidermal growth factor system regulates mucin production in airways. Proc Natl Acad Sci USA 1999; 96: 3081-3086.

33 Ramos-Barbon D, Presley JF, Hamid QA, Fixman ED, Martin JG. Antigen-specific CD4+ T cells drive airway smooth muscle remodeling in experimental asthma. J Clin Invest 2005; 115: 1580-1589.

34 Kiso S, Kawata S, Tamura S, et al. Role of heparin-binding epidermal growth factor-like growth factor as a hepatotrophic factor in rat liver regeneration after partial hepatectomy. Hepatology 1995; 22: 1584-1590.

35 Tolloczko B, Tao FC, Zacour ME, Martin JG. Tyrosine kinase-dependent calcium signaling in airway smooth muscle cells. Am J Physiol Lung Cell Mol Physiol 2000; 278: L1138-L1145.

36 Tolloczko B, Turkewitsch P, Choudry S, Bisotto S, Fixman ED, Martin JG. Src modulates serotonin-induced calcium signaling by regulating phosphatidylinositol $4,5-$ bisphosphate. Am J Physiol Lung Cell Mol Physiol 2002; 282: L1305-L1313.

37 Grynkiewicz G, Poenie M, Tsien RY. A new generation of $\mathrm{Ca}^{2+}$ indicators with greatly improved fluorescence properties. J Biol Chem 1985; 260: 3440-3450.

38 Manning PJ, Rokach J, Malo JL, et al. Urinary leukotriene $\mathrm{E}_{4}$ levels during early and late asthmatic responses. J Allergy Clin Immunol 1990; 86: 211-220.

39 Sapienza S, Eidelman DH, Renzi PM, Martin JG. Role of leukotriene $\mathrm{D}_{4}$ in the early and late pulmonary responses of rats to allergen challenge. Am Rev Respir Dis 1990; 142: 353-358.

40 Wegner CD, Gundel RH, Abraham WM, et al. The role of 5lipoxygenase products in preclinical models of asthma. $J$ Allergy Clin Immunol 1993; 91: 917-929.

41 Eum SY, Maghni K, Hamid Q, Campbell H, Eidelman DH, Martin JG. Involvement of the cysteinyl-leukotrienes in allergen-induced airway eosinophilia and hyperresponsiveness in the mouse. Am J Respir Cell Mol Biol 2003; 28: 25-32.

42 Chu EK, Foley JS, Cheng J, Patel AS, Drazen JM, Tschumperlin DJ. Bronchial epithelial compression regulates epidermal growth factor receptor family ligand expression in an autocrine manner. Am J Respir Cell Mol Biol 2005; 32: 373-380.

43 Ravasi S, Citro S, Viviani B, Capra V, Rovati GE. CysLT receptor-induced human airway smooth muscle cells proliferation requires ROS generation, EGF receptor transactivation and ERK1/2 phosphorylation. Respir Res 2006; 7: 42.

44 Ihaku D, Cameron L, Suzuki M, Molet S, Martin J, Hamid Q. Montelukast, a leukotriene receptor antagonist, inhibits the late airway response to antigen, airway eosinophilia, and IL-5-expressing cells in Brown Norway rats. J Allergy Clin Immunol 1999; 104: 1147-1154. 